\title{
The Course of Chinese Culture's New Life Since the May 4th Movement: From Cultural Awakening to Cultural Self-Confidence
}

\author{
Qinzhao Han \\ School of Marxism \\ Zhejiang University \\ Hangzhou, China 310000
}

\begin{abstract}
The May 4th Movement is the beginning of Chinese culture. Summarizing the development of Chinese culture since the May 4th Movement has important practical significance for enhancing the cultural confidence of the Chinese people and the Chinese nation. Before the May 4th Movement, the changes in Chinese culture were mostly cultural movements led by a few enlighteners, top-down, and lacking a strong leadership core. As a result, they failed to lead Chinese culture to prosperity. After the May 4th Movement, history and people handed over the baton of Chinese cultural development to the Chinese Communist Party. Chinese culture has embarked on the path of cultural renewal led by the Communist Party of China, guided by Marxism and centered on the people, and has achieved the overall awakening of the people. Socialism with Chinese characteristics has entered a new era. Chinese culture has gradually moved toward cultural self-confidence. This has united the consensus for the Chinese dream of realizing the great rejuvenation of the Chinese nation and provided China's wisdom and China's plan for the development of world civilization. The great banner of socialism with Chinese characteristics based on Chinese culture is elevated in the world.
\end{abstract}

Keywords-comprehensive awakening; cultural selfconfidence; the May 4th Movement; course of new life

\section{INTRODUCTION}

This year marks the 100th anniversary of the May 4th Movement and the 70th anniversary of the founding of the People's Republic of China. Summarizing the process of the Chinese Communist Party leading the Chinese people to realize the new life of the national culture is of great practical significance to enhancing the self-confidence of the Chinese people and the Chinese nation, uniting the social consensus, accelerating the building of a socialist modern country, and realizing the Chinese nation's great rejuvenation.

\section{The AtTEMPT OF CUltural Change Before the MAY 4TH Movement: ATtempts By A FEW ENLightened PEOPLE}

The changes in Chinese culture before the May 4th Movement were mostly cultural movements led by a few enlightened people, top-down, and lacking a strong leadership core. After the changes in science and technology, political culture, and ethical culture, Chinese culture was still not prosperous at the time. This shows that Chinese culture cannot be reborn without changing the nature of China's semi-colonial and semi-feudal society and not mobilizing the broad masses of the people.

In the face of serious social problems caused by the Opium War, a small number of people of insight in the feudal intellectuals began to face up to and learn about science and technology. Lin Zexu is the first person in modern China to open his eyes to the world. When he banned opium in Guangzhou, he organized people to translate Western books and magazines, and introduced the geographical and historical conditions of other countries in the world in detail, making "opening the world" an unstoppable cultural trend. Since then, Wei Yuan has further proposed the idea of "learn from foreigners to compete with them" in "Records and Maps of the World", and advocated studying foreign advanced science and technology in order to achieve the goal of enriching the country and resisting external abuse. The "learn from foreigners to compete with them" has realized the ideological leap from "observing foreign countries" to "learning foreign advanced technology" and laid the ideological foundation for the Westernization Movement. The Westernization Group actively promoted modern industry and put forward the idea of "westernized Chinese style" in culture. That is, the Confucian ethical culture is the "subject" and the western science and technology culture is the "method" to achieve the goal of "selfimprovement" and "seeking wealth" and continuing to maintain feudal rule. The fiasco of the Sino-Japanese War declared the Westernization Movement, which was based on the "westernized Chinese style", went bankrupt. In the late Qing Dynasty, intellectuals attempted to maintain the purpose of feudal rule through the transformation of science and technology and determine the destiny of its inevitable defeat. Because the new productive forces are incompatible with the feudal production relations, it is impossible to develop under the shackles of feudalism.

The failure of the Sino-Japanese War of 1894 made the Chinese people realize that learning Western powers only on the material and technical level could not free China from the situation of backward beatings. It must carry out the "legal reform" at the institutional level, and the reform of Chinese 
political culture began. The Reform Movement of 1898 initiated by the bourgeois reformists represented by Kang Youwei and Liang Qichao hopes to adopt the "present item" of the imperial court, implement the reform and reform, and take the path of "Yingdiwang". Kang Youwei launched the "Gongche Shangshu movement" in conjunction with the examinations in Beijing to express the necessity and urgency of the reform. Although the reformists also set up books and set up schools, these activities are basically limited to the small circles of bureaucrats and intellectuals. Because of the fear of the strength of the masses of the people, the inability to mobilize the masses as a guarantee of power, and the inherent weakness of the bourgeois reformists, the Reform Movement of 1898 quickly failed. The failure of the Reform Movement of 1898 led some people to abandon their political reforms and embark on the path of changing the Chinese political culture with the social revolution. The 1911 Revolution led by Sun Yat-sen established the first bourgeois republican government, which enabled the concept of democratic republic to be deeply rooted in the hearts of the people and promoted political and cultural changes, due to the weakness and compromise of the bourgeoisie itself, it is impossible to propose a revolutionary program that is completely anti-imperialist and anti-feudal. Without the leadership of political parties armed with advanced theories, the bourgeois revolutionaries quickly handed over the power to the so-called "strong man"1 who has both new ideas and old means, and naturally gave up the power to lead China's political and cultural changes.

The failure of the Westernization Movement, the Reform Movement of 1898, and the Revolution of 1911 made China's advanced intellectuals increasingly realize that only by breaking the shackles of feudal ethical culture can it be possible to save the country from peril. The May 4th Movement broke out in the brewing.

\section{THE EXPLORATION OF CULTURAL DEVELOPMENT AFTER THE MAY 4TH MOVEMENT: THE CULTURAL AWAKENING OF THE MASSES}

The May 4th Movement promoted the spread of Marxism in China and its integration of the workers and peasants, and it prepared the ideology and cadres for the establishment of the Communist Party of China. Since then, Chinese culture has embarked on the path of cultural new life led by the Communist Party of China, guided by Marxism and centered on the people.

The May 4th Movement promoted the spread of Marxism in China, and the Chinese revolution has since been guided by correct thinking. "Since the Chinese learned MarxismLeninism, the Chinese have been passively transferred to the initiative. From this moment on, the era of looking down on Chinese people and looking down on Chinese culture in the history of modern world should be over." ${ }^{2}$ History has proved that without the guidance of advanced theories, without the leadership of political parties armed with advanced theories,

Ding Weizhi. China's Modern Thoughts, Volume II. Beijing: Social Sciences Academic Press, 2011: 79.

Selected Works of Mao Zedong, Volume 4. Beijing: Chinese People's Publishing House. 1991: 1516. without the support of the broadest masses of the people, achieving national independence and cultural rejuvenation can only be a piece of empty talk. The Westernization Chinese style of the Westernization School fundamentally hopes to learn Western scientific and technological civilization to maintain feudal rule. The reformism of the bourgeois reformers is even more illusory to "reform" without touching the foundation of the feudal economy. The bourgeois revolutionaries did not propose a clear anti-imperialist slogan, hoping to compromise the concession in exchange for imperialism's support for the Chinese revolution. Different from the natural weakness and compromise of the bourgeoisie, the Communist Party of China clearly proposed the democratic revolutionary program with the anti-imperialist and anti-feudal as the struggle goal. The CCP's two majors defeated the warlords, overthrew the imperialist oppression, unified China as the true democratic republic as the current stage of the revolutionary program, and pointed out clear goals for the Chinese people. Under the leadership of the Communist Party of China, the Chinese people adhered to the combination of Marxism and China's reality, carried out a resolute antiimperialist and anti-feudal struggle, and finally won the victory of the new-democratic revolution and changed the semi-feudal and semi-feudal society in China.

The May Fourth Movement promoted the establishment of the Communist Party of China, and the Chinese revolution has since had a strong and unified leadership. The absence of a strong political party leader is an important reason for the failure of the bourgeois democratic revolutionaries. As Tung Meng Hui, who should unite all revolutionary forces, the internal organization is lax, the factions are mixed, and there is no core leadership. Sun Yat-sen deplores that "the internal elements are divided and the steps are messy. There is no spirit of unity and self-government. The virtues of inheritance are not guaranteed. The party leader is equal to the shackles, and the party members have scattered sand. ${ }^{3}$ Unlike the bourgeois revolutionaries, the Chinese Communists were honed in the harsh and difficult struggle environment, forging the spirit of steel, such as the spirit of the Red Boat, the spirit of Jinggangshan and the spirit of the Long March. General Secretary Xi Jinping pointed out: "The great spirit of the Long March is to regard the fundamental interests of the people of the whole country and the Chinese nation above all else, to resolute the ideals and beliefs of the revolution, and to firmly believe in the spirit of the cause of justice. It is the spirit that not afraid of any difficulties and obstacles to save the country and save the people, and will not hesitate to give up all the spirit. It is the spirit of adhering to independence, seeking truth from facts, and proceeding from reality. It is the spirit of taking care of the overall situation, strict discipline, and close unity. It is the spirit of relying closely on the people and the people, living and dying with each other, suffering and sharing, and arduous struggle." ${ }^{4}$ The great spirit of the Long March is a concentrated expression of the firm revolutionary ideals of the

Sun Yat-sen's Complete Works, Volume 3, Beijing: Zhonghua Book Company Edition, 2011: 165.

Selected works of important literature since the 18th National Congress (below) [Z]. Beijing Central Literature Publishing House, 2018:395. 
Chinese Communists and a vivid reflection of the Chinese people's hard-working national spirit.

The May 4th Movement promoted the combination of the Communists and the workers and peasants. The Chinese Communist Party has always relied on the masses and mobilized the masses to promote the overall awakening of the Chinese people and the Chinese nation. At the beginning of the founding of the Communist Party of China, we adhered to the rural encirclement of urban routes, focusing on rural areas and mobilizing the masses in rural areas. The implementation of the comprehensive war of resistance is a concentrated expression of this thinking and a more comprehensive and thorough spiritual awakening conducted by the party leading the people throughout the country. The Kuomintang regime, which represents the interests of the big landlords and the big bourgeoisie, does not dare to rely on and mobilize the masses to implement a one-sided war of resistance. The Communist Party of China is convinced that only by mobilizing and relying on the masses and carrying out a protracted war can the final victory be achieved. Therefore, the Chinese Communist Party has focused its work on the countryside behind the enemy, actively opened up the enemy's back battlefield, and continued to follow the route of "surround the cities from the countryside".

\section{NEW LifE OF Chinese Culture: TOWARdS CUltural SELF-CONFIDENCE IN PRACTICE EXPLORATION}

After the founding of New China, the Chinese Communist Party led the Chinese people to gradually embark on a road of socialist cultural construction with Chinese characteristics. Entering a new era, the Chinese people and the Chinese nation have gradually moved toward cultural self-confidence, and have reached consensus on the Chinese dream of realizing the great rejuvenation of the Chinese nation and provided China's wisdom and China's plan for the development of world civilization. The great banner of socialism with Chinese characteristics based on Chinese culture is elevated in the world.

In the new era, cultural self-confidence is systematically developed. First, the basic connotation of cultural selfconfidence is clarified. Xi Jinping clearly pointed out in the "July 1" speech that "the Chinese traditional culture cultivated in the 5,000 years of civilization development, the revolutionary culture and the advanced socialist culture fostered in the great struggle of the party and the people, accumulate the deepest spirit pursuit of the Chinese nation, represent the unique spiritual identity of the Chinese nation." It can be seen that the connotation of cultural self-confidence includes traditional cultural self-confidence, revolutionary cultural self-confidence and socialist advanced culture selfconfidence. The establishment of cultural self-confidence has laid a solid foundation for the in-depth study of cultural selfconfidence. Second, the "four self-confidence" theory is put forward, emphasizing that cultural self-confidence is a more basic, broader and deeper self-confidence. Cultural selfconfidence provides deep cultural support for road selfconfidence, theoretical self-confidence and institutional selfconfidence. The road of socialism with Chinese characteristics is the choice of history and people. This choice itself is consistent with the value orientation of Chinese culture. The theoretical system of socialism with Chinese characteristics is a scientific theory based on the forefront of the times and advancing with the times. There is no precedent to follow, and strong cultural self-confidence is needed to provide theoretical strength. The socialist system with Chinese characteristics has distinctive Chinese characteristics. It does not copy the Western model, and does not succumb to self-restraint and self-respect. It requires a firm cultural confidence to take its own path. The "four self-confidences" complement each other, dialectical unity, and together constitute a complete cultural theory. The systematic presentation of cultural self-confidence has important practical value.

Second, cultural self-confidence is to unite people's consensus. First of all, cultural self-confidence embodies the Chinese spirit and promotes the leadership of ideological work. Ideology is about flags and roads. Cultural self-confidence makes the whole people firmly unite in the ideals, beliefs, values and moral concepts, consolidates the guiding position of Marxism in the field of ideology, and firmly grasps the leadership of ideological work. Second, cultural selfconfidence embodies Chinese values and is conducive to nurturing and practicing socialist core values. "It is necessary to make clear the historical origins, development context, and basic direction of China's excellent traditional culture, and the unique creation, values, and distinctive characteristics of Chinese culture, and enhance cultural self-confidence and confidence in values." Culture is an important source of values. The core values of socialism are based on the fine traditional Chinese culture and revolutionary culture, and are cast into the advanced socialist culture. Therefore, cultural self-confidence is an important premise for cultivating and practicing the core values of socialism, and it helps them to play an important role in cohesiveness and maintaining national spirit. Third, cultural self-confidence unites China's strength and leads and promotes comprehensive deepening of reforms. The new era is an era in which the people of all nationalities in the country unite and struggle, constantly create a better life, and gradually realize the common prosperity of all the people.

Finally, cultural self-confidence provides China's wisdom and China's program for the development of world civilization. The great banner of socialism with Chinese characteristics based on Chinese culture is lifted high in the world. With the advancement of economic globalization and multi-polarization of the world, on the one hand, the links between economy, politics and culture are increasingly close. Culture has become an important factor in the country's comprehensive national strength competition, and cultural exchanges between the international communities have become increasingly frequent. On the other hand, the world is in a period of great development, great change, great adjustment, instability, lack of certainty, and the international community urgently needs to build a more just and reasonable international system and order. Since the 18th National Congress, the party and state undertakings have undergone historic changes, and socialism with Chinese characteristics has entered a new era. China's development concept has been increasingly recognized. China has the confidence and ability to make greater contributions to the world. Based on the new international and domestic 
situation, General Secretary Xi Jinping proposed the idea of constructing a community with shared future for mankind. This provides China's wisdom and China's program for the development of world civilization. "In today's world, countries are interdependent and co-existing. People need to inherit and carry forward the purposes and principles of the UN Charter, build a new type of international relations with cooperation and win-win, and build a community with shared future for mankind." 5 To build a community with shared future for mankind, in terms of culture, people need to respect the diversity of world civilizations, to communicate with civilizations, to transcend civilizations, to learn from civilizations, to surpass civilizations, and to coexist with civilizations. Cultural differences should not be the root of conflict, but should be the driving force for the progress of human civilization.

\section{CONCLUSION}

It will be necessary to grasp the logic of Chinese cultural development in a historical and holistic manner, especially the development of Chinese culture since the May 4th Movement. People need to understand profoundly that the party's leadership of the Chinese nation to achieve cultural renaissance is the choice of history and people, and it is the right choice to pass the practice test and stand the test of practice. This is of great significance to enhancing cultural self-confidence, maintaining political strength, and pushing the cause of socialism with Chinese characteristics to a new starting point.

\section{REFERENCES}

[1] Ding Weizhi. China's Modern Thoughts, Volume II. Beijing: Social Sciences Academic Press, 2011: 79. (in Chinese)

[2] Selected Works of Mao Zedong, Volume 4. Beijing: Chinese People's Publishing House. 1991: 1516. (in Chinese)

[3] Sun Yat-sen's Complete Works, Volume 3, Beijing: Zhonghua Book Company Edition, 2011: 165. (in Chinese)

[4] Selected works of important literature since the 18th National Congress (below) [Z]. Beijing Central Literature Publishing House, 2018:395. (in Chinese)

[5] Xi Jinping, The Governance of China, volume II, Foreign Languages Press, 2017: 522.(in Chinese)

\footnotetext{
5 Xi Jinping, The Governance of China, volume II, Foreign

Languages Press, 2017: 522.
} 